\title{
PENGEMBANGAN MEDIA LECTUREMAKER DALAM PEMBELAJARAN KIMIA SMA POKOK BAHASAN IKATAN KIMIA MELALUI PENERAPAN PROFESSIONAL LEARNING COMMUNITY
}

Ajeng Gentry Pangastuty ${ }^{1}$, Dr. Ucu Cahyana, M.Si. ${ }^{2}$, dan Dr. Agung Purwanto, M.Si. ${ }^{3}$

1 Jurusan Pendidikan kimia Fakultas Matematika dan IImu Pengetahuan Alam, Universitas Negeri Jakarta. Jl. Pemuda No.10 Rawamangun Jakarta. Indonesia

2,3 Pembimbing Jurusan kimia Fakultas Matematika dan Ilmu Pengetahuan Alam, Universitas Negeri Jakarta Jl. Pemuda No.10 Rawamangun Jakarta. Indonesia

\begin{abstract}
Abstrak
Penelitian ini bertujuan untuk memberikan alternatif media pembelajaran kimia yang lebih menarik dengan menghasilkan LectureMAKER melalui penerapan Professional Learning Community pada pokok bahasan Ikatan Kimia kelas $X$ semester genap di SMA. Metode penelitian yang digunakan adalah metode penelitian dan pengembangan (research and development). Tahap pengembangan LectureMAKER dalam penelitian ini meliputi: analisis kebutuhan, pengembangan media pembelajaran yang dikerjakan secara kolaborasi dengan guru-guru, uji kelayakan produk, dan revisi produk. LectureMAKER hasil pengembangan dikaji oleh pengkaji materi dan media dan juga oleh murid dan guru. Hasil analisis uji coba LectureMAKER memperoleh penilaian yang layak dari tim ahli, guru, dan siswa. Hasil penelitian ini menunjukkan bahwa LectureMAKER melalui penerapan Professional Learning Community pada materi Ikatan Kimia yang dikembangkan sudah baik dan layak untuk dijadikan sebagai alternative media pembelajaran dalam pembelajaran KIMIA SMA Negeri dan Sederajat untuk kelas $\mathrm{X}$.
\end{abstract}

Kata Kunci : LectureMAKER, Ikatan Kimia, Professional Learning Community, Research and Development

\begin{abstract}
This study aims to provide an alternative media learning chemistry more interesting by generating LectureMAKER through the implementation of Professional Learning Community on the subject of class $X$ Chemical Bonding semester in high school. The method used is the method of research and development (research and development). LectureMAKER development phase of this research include: needs analysis, instructional media development done in collaboration with teachers, due diligence products and product revisions. LectureMAKER development outcomes assessed by the assessment of materials and media, and also by students and teachers. The results of the analysis of test LectureMAKER obtain adequate assessment of the team of experts, teachers, and students. The results of this study indicate that LectureMAKER through the implementation of Professional Learning Community at the Institute of Chemistry, developed the material is good and worthy to serve as an alternative medium of learning in learning CHEMICAL SMA and equal to the class $X$.
\end{abstract}

Keywords: LectureMAKER, Chemical Bonding, Professional Learning Community, Research and Development

\section{PENDAHULUAN}

Pada bidang pengajaran, penggunaan komputer sebagai media pembelajaran memungkinkan untuk terselenggaranya proses belajar mengajar jarak jauh, atau pembelajaran tanpa tatap muka. Namun demikian dalam pelaksanaannya mengalami beberapa hambatan. Pengajar dalam hal ini, guru yang menguasai materi pelajaran, sebagian besar tidak mampu menghadirkan bentuk pelajaran dalam komputer, sedangkan ahli komputer yang mampu merealisasikan segala hal dalam komputer biasanya tidak menguasai materi pelajaran. Untuk mengatasi masalah tersebut, tentunya dibutuhkan suatu kerja sama yang baik antara pengajar dengan ahli komputer. Ahli komputer bertugas membuat suatu program yang mudah digunakan, dengan perangkat lunak tertentu, yang akan memudahkan pengajar merealisasikan ide-idenya sesuai dengan materi pelajaran yang dikuasainya dalam komputer.

Ilmu Kimia merupakan mata pelajaran yang kompleks, dimana siswa dituntut memiliki kemampuan memahami konsep yang diikuti 
dengan kemampuan berhitung memecahkan soal. Dalam mata pelajaran Kimia yang sarat dengan konsep, dari konsep yang sederhana sampai konsep yang lebih kompleks dan abstrak, sangatlah diperlukan pemahaman yang benar terhadap konsep dasar yang membangun. konsep tersebut. Banyaknya konsep Kimia yang bersifat abstrak yang harus di serap siswa dalam waktu relatif terbatas menjadikan ilmu Kimia merupakan salah satu mata pelajaran yang cukup sulit bagi siswa sejak dahulu.

Berdasarkan hasil observasi yang dilakukan di SMA Negeri 31 Jakarta, materi yang dirasakan sulit oleh siswa adalah materi Ikatan Kimia. Masih sekitar 37,1\% siswa menyatakan sulit terhadap materi tersebut pada hasil angket yang diberikan ke siswa. Selain itu, kesulitan mengelompokkan bentuk-bentuk ikatan yang terjadi. Oleh karena itu, guru mata pelajaran Kimia dituntut untuk lebih kreatif sehingga dapat menghasilkan pembelajaran Kimia yang baik, menarik dan menyenangkan. Dengan demikian, dapat tercipta pembelajaran Kimia yang menarik yang dapat meningkatkan kualitas pembelajaran.

Untuk mengatasi hal ini, salah satunya adalah dengan membuat media pembelajaran. Media pembelajaran merupakan wahana dan penyampaian informasi atau pembelajaranpada siswa. Melalui adanya media pada proses belajar mengajar, diharapkan dapat membantu guru dalam meningkatkan prestasi belajar pada siswa. Oleh karena itu, guru hendaknya menghadirkan media dalam setiap proses belajar demi tercapainya tujuan pembelajaran.Salah satu upayanya adalah dengan media pembelajaran LectureMAKER.

LectureMAKER merupakan salah satu software multimedia yang banyak diaplikasikan untuk media pembelajaran.

Kelebihan dari software ini adalah dapat diwujudkan dalam bentuk presentasi, CD interaktif dan online melalui web.
Software LecturerMAKER dilengkapi dengan program pembuatan audio video, sehingga sangat memungkinkan untuk multimedia interaktif.Media yang dibuat diharapkan dapat memotivasi siswa untuk belajar, karena menampilkan penyajian materi secara menarik dan informatif.

Guru secara kolaborasi dapat membicarakan suatu masalah, menganalisis penyebabnya secara mendetail, dan memikirkan bersama pemecahan masalahnya. Guru dan rekan sejawatnya dapat berkolaborasi untuk menghasilkan media pembelajaran LectureMAKER yang baik. Rekan kolaborasi dapat memberikan ide-idenya mengenai pembuatan dan cara penggunakan media LectureMAKER, sehingga diperoleh media LectureMAKER yang efektif, menarik, dan interaktif serta menyenangkan. Kolaborasi guru dalam merancang media LectureMAKER didasarkan pada kebutuhan dan masalah yang ada. Kolaborasi guru tersebut merupakan penerapan program Professional Learning Community (PLC).

Oleh karena itu, penelitian ini diharapkan dapat mengembangkan media pembelajaran LectureMAKER yang sesuai kebutuhan siswa kelas $X$ dan memvisualisasikan materi lkatan Kimia melalui penerapan Professional Learning Community di SMA Negeri 31 Jakarta.

\section{METODOLOGI PENELITIAN}

\section{A. Metode Penelitian}

Metode yang digunakan dalam penelitian ini adalah metode penelitian dan pengembangan (Research and Development). Tahapan-tahapan penelitian dilakukan analisis produk yang akan dikembangkan (analisis kebutuhan), mengembangkan produk,dan uji coba produk.
B. Prosedur Penelitian
Prosedur pelaksanaan pada penelitian ini meliputi beberapa tahap penelitian pengembangan yang mengacu pada prosedur 
Tabel 1. Skala Penilaian Instrumen Penelitian

\begin{tabular}{|c|l|c|c|}
\hline \multirow{2}{*}{ No } & \multirow{2}{*}{$\begin{array}{c}\text { Alternatif } \\
\text { Jawaban }\end{array}$} & $\begin{array}{c}\text { Pertanyaan } \\
\text { atau } \\
\text { Pertanyaan } \\
\text { Positif }\end{array}$ & $\begin{array}{c}\text { Pertanyaan } \\
\text { atau } \\
\text { Pertanyaan } \\
\text { Negatif }\end{array}$ \\
\hline 1. & $\begin{array}{l}\text { Sangat } \\
\text { Setuju }\end{array}$ & 4 & 1 \\
\hline 2. & Setuju & 3 & 2 \\
\hline 3. & Tidak Setuju & 2 & 3 \\
\hline 4. & $\begin{array}{l}\text { Sangat Tidak } \\
\text { Setuju }\end{array}$ & 1 & 4 \\
\hline
\end{tabular}

Untuk batas baik tidaknya bahan ajar yang didasarkan pada kriteria interpretasi skor untuk Skala Linkert sebagai berikut[1] :

\begin{tabular}{|l|l|}
\hline Presentase & Interpretasi \\
\hline Angka $0 \%-20 \%$ & Sangat Kurang \\
\hline Angka $20 \%-40 \%$ & Kurang \\
\hline Angka $40 \%-60 \%$ & Cukup \\
\hline Angka $60 \%-80 \%$ & Baik \\
\hline Angka $80 \%-100 \%$ & Sangat Baik \\
\hline
\end{tabular}

Borg dan Gall(19...) yang disederhanakan menjadi beberapa tahap ${ }^{5}$, yaitu:

1. Analisis kebutuhan, meliputi kendala dan kebutuhan guru maupun siswa, mengidentifikasi kebutuhan dalam pembuatan media LectureMAKER, dan mengetahui pendapat siswa dan guru mngenai pembuatan LectureMAKER.

2. Pengembangan produk

Dalam mengembangkan produk,membuat skenario media LectureMAKER dan menghasilkan media LectureMAKER. Adapun komponen-komponen yang akan dikembangkan pada produk antara lain:
a. Materi.
b. Kompetensi yang akan dicapai.
c. Soal latihan
3. Uji coba produk

a. Uji coba kepada tim ahli (expert judgement) bertujuan untuk mengetahui validitas (kelayakan) media LectureMAKER, baik dari segi materi dan media sehingga diperoleh informasi berupa perbaikan, saran, dan kritik untuk evaluasi dan revisi LectureMAKER yang dihasilkan.

b. Uji coba kelompok kecil bertujuan untuk meminta masukan mengenai LectureMAKER yang telah direvisi tim ahli materi, dan media. Dalam tahap ini melibatkan sekelompok kecil siswa sebagai responden dengan menggunakan angket uji coba.

c. Uji coba kelompok besar bertujuan mengetahui sejauh mana penerimaan siswa dan guru terhadap media LectureMAKER yang dihasilkan. Kegiatan yang dilakukan yaitu survei angket diberikan kepada siswa setelah melihat tampilan LectureMAKER yang disajikan. Kemudian dilakukan pengolahan data serta analisis data.

\section{Instrumen Penelitian}

Penelitian ini menggunakan empat jenis angket sebagai instrumen penelitian, yaitu angket analisis kebutuhan, angket penilaian ahli materi, angket penilaian ahli media, dan angket penilaian siswa. Angket-angket tersebut dibuat berdasarkan standar penilaian bahan ajar oleh BSNP (Badan Standar Nasional Pendidikan).

\section{F. Teknik Analisis Data}

Skala penilaian instrumen penelitian terdapat pada tabel 1 sebagai berikut:

\section{HASIL PENELITIAN}

1. Hasil Uji Ahli Materi

Media pembelajaran kimia lecturer MAKER TELAh dihasilkan melalui penerapan Professional Learning Community pada pokok bahasan Ikatan Kimia kelas $X$ semester genap di SMA. kemudian diuji kelayakannya oleh ahli materi,ahli media, uji kelompok kecil dan uji kelompok besar. Hasil uji menurut ahli materi 
Tabel 3. Hasil Penilaian Ahli Materi

\begin{tabular}{|c|c|c|c|c|c|}
\hline No & Indikator & $\begin{array}{l}\text { Nomer } \\
\text { Angket }\end{array}$ & $\begin{array}{c}\% \\
\text { (interpretasi } \\
\text { ) }\end{array}$ & Validitas & Reabilitas \\
\hline 1 & $\begin{array}{l}\text { Kualitas } \\
\text { relevansi } \\
\text { dengan } \\
\text { kompetensi }\end{array}$ & 1,2 & $\begin{array}{c}79,2 \\
\text { (Sangat } \\
\text { Baik) }\end{array}$ & $\begin{array}{c}0,81 \\
\text { (Sangat } \\
\text { Tinggi) }\end{array}$ & \multirow{2}{*}{$\begin{array}{c}0,77 \\
\text { (Reliable) }\end{array}$} \\
\hline 2 & Kualitas Isi & $\begin{array}{c}3,4,5,6 \\
7,8,9 \\
10,11 \\
12,13\end{array}$ & $\begin{array}{c}88,6 \\
\text { (Sangat } \\
\text { Baik) }\end{array}$ & $\begin{array}{c}0,91 \\
\text { (Sangat } \\
\text { Tinggi) }\end{array}$ & \\
\hline 3 & $\begin{array}{l}\text { Kualitas } \\
\text { Keseluruhan } \\
\text { Isi }\end{array}$ & $\begin{array}{c}1,2,3,4 \\
5,6,7,8 \\
9,10,11 \\
12,13\end{array}$ & $\begin{array}{c}87,2 \\
\text { (Sangat } \\
\text { Baik) }\end{array}$ & - & - \\
\hline
\end{tabular}

Tabel 4. Hasil Penilaian Ahli Media

\begin{tabular}{|c|l|c|c|c|c|}
\hline No & \multicolumn{1}{|c|}{ Indikator } & Nomer Angket & $\begin{array}{c}\% \\
\text { (interpretasi) }\end{array}$ & Validitas & Reabilitas \\
\hline 1 & Desain Visual & $1,2,3,4$ & $\begin{array}{c}83,33 \\
\text { (Sangat Baik) }\end{array}$ & $\begin{array}{c}0,98 \\
\text { (Sangat Tinggi) }\end{array}$ & $\begin{array}{c}0,76 \\
\text { (Reliabel) }\end{array}$ \\
\cline { 1 - 4 } 2 & Struktur dan Navigasi & $5,6,7,8$ & $\begin{array}{c}91,67 \\
\text { (Sangat Baik) }\end{array}$ & $\begin{array}{c}0,87 \\
\text { (Sangat Tinggi) }\end{array}$ & - \\
\hline 3 & Kualitas Keseluruhan & $\begin{array}{c}8,2,3,4,5, \\
6,7,8\end{array}$ & $\begin{array}{c}87,50 \\
\text { (Sangat Baik) }\end{array}$ & - \\
\hline
\end{tabular}

Tabel 5. Hasil Penilaian Uji Kelompok Kecil

\begin{tabular}{|c|c|c|c|c|c|}
\hline No. & Indikator & Nomer Angket & $\begin{array}{c}\% \\
\text { (Interpretasi) }\end{array}$ & Validitas & Reliabilitas \\
\hline 1. & Tampilan & 3 dan 4 & $\begin{array}{c}82,50 \\
\text { (Sangat Baik) }\end{array}$ & $\begin{array}{c}0,76 \\
\text { (Tinggi) }\end{array}$ & \multirow{4}{*}{$\begin{array}{c}0,73 \\
\text { (Reliabel) }\end{array}$} \\
\hline 2. & Isi & 1 dan 2 & $\begin{array}{c}86,25 \\
\text { (Sangat Baik) }\end{array}$ & $\begin{array}{c}0,67 \\
\text { (Tinggi) }\end{array}$ & \\
\hline 3. & Sitem Navigasi & 5 dan 6 & $\begin{array}{c}85,00 \\
\text { (Sangat Baik) }\end{array}$ & $\begin{array}{c}0,70 \\
\text { (Tinggi) }\end{array}$ & \\
\hline 4. & Desain Visual & $7,8,9,10,11$ & $\begin{array}{c}82,50 \\
\text { (Sangat Baik) }\end{array}$ & $\begin{array}{c}0,72 \\
\text { (Tinggi) }\end{array}$ & \\
\hline 5. & $\begin{array}{l}\text { Kualitas } \\
\text { Keseluruhan }\end{array}$ & $\begin{array}{c}1,2,3,4,5,6 \\
7,8,9,10,11\end{array}$ & $\begin{array}{c}83,64 \\
\text { (Sangat Baik) }\end{array}$ & - & - \\
\hline
\end{tabular}

ditunjukkan pada Tabel 3. Dari tabel 3 dapat dilihat bahwa baik kualitas isi, maupun kualitas relevansi dengan kompetensi mempunyai nilai masing masing 79,2\% dengan kategori sangat baik, dan 88, 6 dengan kategori sangat baik. Secara keseluruhan media pembelaaran lecturr MAKER yag dihasikan ditinjau dari segi materi sangat baik ditunjukkan pada Tabel 3.
Dari tabel 3 dapat dilihat bahwa baik kualitas isi, maupun kualitas relevansi dengan kompetensi mempunyai nilai masing masing 79,2\% dengan kategori sangat baik, dan 88, 6 dengan kategori sangat baik. Secara keseluruhan media pembelaaran lecturr MAKER yag dihasikan ditinjau dari segi materi sangat baik 
Tabel 6. Hasil Penilaian Uji Kelompok Besar

\begin{tabular}{|c|l|c|c|l|}
\hline No. & \multicolumn{1}{|c|}{ Indikator } & Nomer Angket & $\%$ & Interpretasi \\
\hline 1. & Tampilan & 3 dan 4 & 79,93 & Sangat Baik \\
\hline 2. & Isi & 1 dan 2 & 85,53 & Sangat Baik \\
\hline 3. & Sistem Navigasi & 5 dan 6 & 84,87 & Sangat Baik \\
\hline 4. & Desain Visual & $7,8,9,10,11$ & 81,32 & Sangat Baik \\
\hline 5. & Kualitas Keseluruhan & $1,2,3,4,5,6,7,8,9$, & 84,91 & Sangat Baik \\
& & 10,11 & & \\
\hline
\end{tabular}

\section{Hasil Uji Ahli Media}

Media pembelajaran kimia lecturer MAKER TELAh dihasilkan melalui penerapan Professional Learning Community pada pokok bahasan Ikatan Kimia kelas $X$ semester genap di SMA. kemudian diuji kelayakannya oleh ahli media. Hasil uji menurut ahli media ditunjukkan pada Tabel 4. Dari tabel 4 dapat dilihat bahwa baik disain visual maupun struktur navigasi maupun kualitas relevansi dengan kompetensi mempunyai nilai masing masing 83,3\% dengan kategori sangat baik, dan 91,67 dengan kategori sangat baik. Secara keseluruhan media pembelaaran lecturr MAKER yag dihasikan ditinjau dari segi media sangat baik

\section{Hasil Uji Kelompok kecil}

Media pembelajaran kimia lecturer MAKER TELAh dihasilkan melalui penerapan Professional Learning Community pada pokok bahasan Ikatan Kimia kelas $X$ semester genap di SMA. kemudian diuji kelayakannya oleh

kelompok kecil. Hasil uji menurut ahli materi ditunjukkan pada Tabel 3. Dari tabel 34dapat dilihat bahwa baik kualitas isi, tampilan, sistem navigasi dan desain visual mempunyai nilai masing masing $79,9 \%$, $85,63,84,57$, 81,32 dan 84, 91 dengan kategori sangat baik. Secara keseluruhan media pembelaaran lecturr MAKER yag dihasikan ditinjau dari uji terhadap kelompok kecil sangat baik

4. Uji Pada kelompok Besar

Berdasarkan hasil persentase observasi uji coba media LectureMAKER pada kelompok besar, dapat disimpulkan bahwa semua indikator memiliki persentase $83,64 \%$ yang diperoleh dari hasil analisis kuesioner yang sudah diukur validitas dan reliabilitasnya dengan interpretasi yang sangat baik. Hal ini menandakan bahwa media pembelajaran LectureMAKER dapat digunakan sebagai alternatif media pembelajaran untuk materi Ikatan Kimia.

\section{KESIMPULAN}

Berdasarkan

hasil

penelitian pengembangan ini dapat disimpulkan bahwa media pembelajaran KimiaLectureMAKER yang dikembangkan melalui penerapan Professional Learning Community pada materi Ikatan Kimia yang dilengkapi kompetensi, materi, latihan soal serta animasi bergerak dinyatakan baik dan layak untuk digunakan dalam pembelajaran Kimia yang sesuai dengan kebutuhan siswa. Media pembelajaran LectureMAKER memuat tiga sub materi pokok yaitu, pengenalan Ikatan Kimia, teori duplet dan oktet, dan Ikatan Kimia. Dan di akhir materi terdapat latihan untuk mengulang 
materi yang telah dipelajari dan juga nilai yang didapat langsung di monitor.

Berdasarkan hasil penelitian, pengembangan media pembelajaran Kimia pada materi Ikatan Kimia melalui penerapan Profesional Learning Community dapat meningkatkan kemudahan siswa dalam mempelajari materi dan membantu guru dalam mengajar, karena media ini berperan juga sebagai bahan ajar alternatif mengajar guru. Selain itu, dapat dijadikan sebagai alat evaluasi pembelajaran untuk melihat pencapaian kompetensi berdasarkan indikator keberhasilan yang ditetapkan.

\section{UCAPAN TERIMA KASIH}

1. Peneliti ingin menyampaikan terima kasih kepada Dr.Ucu Cahyana,M.Si. dan Dr.Agung Purwanto,M.Si. selaku dosen pembimbing sehingga penulisan skripsi ini dapat terselesai

\section{DAFTAR PUSTAKA}

[1] Arikunto. 2002. Dasar-dasar Evaluasi Pendidikan. Jakarta : Bumi Aksara

[2] Badan Standar Nasional Pendidikan. 2006. Instrumen penilaian tahap II. Jakarta: BSNP.

[3] Iyam. LectureMAKER Terbaru. http://islam-download.net/software-free-gratisterbaru/education-software-free-gratis-terbaru/LectureMAKER-terbaru.html.Akses pada 12 April 2011

[4] Misbah, Zainun. Pemimpin Komunitas Pembelajaran. Direktorat Tenaga Kependidikan Ditjen, PMPTK Depdiknas.

[5] Tim Puslitjaknov.2008. Metode Penelitian dan Pengembangan. Jakarta: Depdiknas

[6] Sugiyono. 2010. Metode Penelitian Kuantitatif Kualitatif dan R\&D. Bandung : Alfabeta. hlm 287-313 